\title{
Population Growth Potential of Bracon brevicornis Wesmael (Braconidae: Hymenoptera): A Life Table Analysis
}

\author{
T. SRINIVASAN ${ }^{1} *$ and CHANDRIKAMOHAN ${ }^{2}$ \\ ${ }^{1 *}$ Coconut Research Station, Tamil Nadu Agricultural University, Aliyarnagar, Tamil Nadu - 642 101, India \\ ${ }^{2}$ ICAR-Central Plantation Crops Research Institute Regional Station, Kayankulam, Kerala - 690 533, India
}

(Received: 11 November 2016; accepted: 2 January 2017)

\begin{abstract}
A laboratory experiment was conducted at the Biocontrol laboratory, Coconut Research Station, Aliyarnagar to study the life table parameters of Bracon brevicornis Wesmael, a parasitoid of the coconut blackheaded caterpillar, Opisina arenosella Walker on its established laboratory host, Corcyra cephalonica Stainton. Studies at $28.3 \pm 0.1{ }^{\circ} \mathrm{C}$ and $59.6 \pm 0.6 \%$ r.h. revealed that the net reproductive rate $\left(\mathrm{R}_{\mathrm{o}}\right)$ of $B$. brevicornis was 39.52 females/female when reared on $C$. cephalonica larvae. The precise generation time $(\mathrm{T})$ was 13.33 days. The intrinsic rate of natural increase $\left(\mathrm{r}_{\mathrm{m}}\right)$ was 0.2758 which was slightly higher than the innate capacity for increase $\left(r_{c}=0.2504\right)$. The weekly multiplication rate was 6.893 numbers while 1561.83 females could be expected in the $\mathrm{F}_{2}$ generation. Higher net reproductive rate, coupled with shorter population doubling time of $B$. brevicornis indicate the efficacy of the parasitoid as a suitable candidate for the management of coconut black headed caterpillar, $O$. arenosella, its intended host under field conditions.
\end{abstract}

Keywords: Population growth potential, life table, Bracon brevicornis.

Biological control agents are gaining increased attention in the recent years due to their environmental feasibility, eco-friendliness and sustainability. Coconut (Cocos nucifera L.) is a perennial plantation cum oil seed crop grown in India with more than 10 million people depending upon it for livelihood (Nampoothiri and Thomas, 2000). Coconut is grown in an area of 1.97 million ha with an annual production of 20,439 million tonnes (CDB, 2016). Among the several pests attacking the palm, the black headed caterpillar (Opisina arenosella Walker) is one of the serious lepidopterous pests causing damage by scrapping the photosynthetic material from the abaxial surface of the leaves and making galleries of excreta on the under surface of the leaves. This leads to reduction in the photosynthetic efficiency and thereby cause yield reduction to the tune of 30-40 per cent (Mohamed, 1980). Being a tree crop and attaining a height of even 25 to 40 feet, the black headed caterpillar management poses a serious hurdle in that, the plant protection measures such as insecticidal sprays do more harm than good to the plant protection worker as well as to the ecosystem besides being harmful to non-target organisms and natural enemies. Species belonging to the order Hymenoptera have been recorded mainly as par-

* Corresponding author; e-mail: entosrini@gmail.com 
asitoids of $O$. arenosella. Thus biocontrol agents, especially the larval parasitoids Bracon brevicornis Wesmael and Goniozus nephantidis Muesebeck serve as effective parasitoids for the management of $O$. arenosella under field conditions (Cock and Perera, 1987). Adult females of $B$. brevicornis lay about 25 eggs on the larva of $O$. arenosella. The eggs hatch out in 2-3 days and the emerging larvae survive on the host larvae (O. arenosella) for 2-3 days. The pupal stage lasts about 3-4 days and the emerging adults go in search of new host larvae (Narendran, et al., 1980; Rukshana and Majeed, 2014). Release of larval parasitoids alone can bring about 83 per cent reduction in the pest population (Nair, 1993). This paper is an attempt to study the life table parameters of the parasitoid, B. brevicornis on one of its laboratory host, Corcyra cephalonica Stainton under laboratory conditions.

Life table studies of parasitoids and predators provide necessary information on their effectiveness against target pests, rate of population build up, etc. under laboratory conditions which can be correlated to natural conditions (Muthukrishnan et al., 1995) and to schedule period of intervals for parasitoid releases. Life table computation helps in studying the population dynamics of the insect species and is an analytical tool which provide a description of the survivorship, development, etc., and reveal the maximum growth potential of a population (Gabre et al., 2004).

\section{Materials and Methods}

Rearing of C. cephalonica

To maintain the $C$. cephalonica culture, eggs were placed in coarsely broken sorghum (Sorghum bicolor L. Moench.) grains in plastic trays $(39 \mathrm{~cm} \mathrm{dia.} \times 14 \mathrm{~cm}$ height). The setup was left undisturbed at room temperature $\left(28.3 \pm 0.1{ }^{\circ} \mathrm{C}\right.$ and $59.6 \pm 0.6 \%$ r.h. $)$ for about 45 to 55 days and the emerging adults were collected, paired in an open transparent glass beaker $(10 \mathrm{~cm}$ dia. $\times 23 \mathrm{~cm}$ height) for about two to three days. The female adults loosely lay their eggs inside the beaker which can be sieved through a 30 mesh sieve. The collected eggs are placed in fresh broken sorghum grains for continuous rearing.

Rearing of Bracon brevicornis

Fully grown larva (from the above set up) forms the substratum for the braconid, B. brevicornis. Known number of full grown C. cephalonica larva were collected and placed on a tissue paper covering an open glass beaker $(10 \mathrm{~cm} \mathrm{dia} . \times 23 \mathrm{~cm}$ height). Immediately, a ghada cloth was placed on the larvae to arrest their movement to facilitate parasitisation by the parasitoids which were previously placed in the container. This is referred to as the Sandwich method (tissue paper - larvae - ghada cloth) that is widely followed for rearing B. brevicornis parasitoids (Jhansi, 1984). The tissue paper gives way for parasitisation of the larva placed above it and within 24 to $48 \mathrm{~h}$, the larvae gets parasitized. After about 6 to 8 days, the ghada cloth was removed and the tissue paper containing the pupal stages of the parasitoid were placed in separate beakers $(10 \mathrm{~cm}$ dia. $\times 23 \mathrm{~cm}$ height $)$ along with a cotton swab containing honey which serves as food for the emerging parasitoids. 


\section{Life table studies}

In order to perform life table studies, the C. cephalonica larvae and B. brevicornis aduts from the above culture were used. The laboratory studies were performed at room temperature $28.3 \pm 0.1{ }^{\circ} \mathrm{C}$ and $59.6 \pm 0.6 \%$ r.h. One pair of freshly emerged $B$. brevicornis was placed in a transparent glass vial $(2 \mathrm{~cm}$ dia. $3.5 \mathrm{~cm}$ height $)$ containing full grown $5^{\text {th }}$ instar larva of $C$. cephalonica and plugged with cotton wool. A small cotton swab soaked in honey was placed inside the vial to serve as food for the parasitoids. The parasitoids were transferred to a new vial containing a full grown larva of $C$. cephalonica each day at a specific time until the female dies. Twenty-five such vials (representing 25 replicates) were maintained and the experiment was continued until the females in all the 25 vials died naturally. The larval mortality, pupal mortality, sex ratio, longevity of male and female, etc. were studied along with other life table parameters, viz. net reproductive rate $\left(R_{o}\right)$, approximate generation time $\left(T_{c}\right)$, intrinsic rate of natural increase $\left(r_{m}\right)$, innate capacity for increase $\left(r_{c}\right)$, finite rate of increase $(\lambda)$, mean generation time $(T)$, population doubling time $(\mathrm{t})$, weekly multiplication rate (WMR) and hypothetical female in $\mathrm{F}_{2}$ generation $\left(\mathrm{R}_{\mathrm{o}}{ }^{2}\right)$ as per the methodology of Venkatesan et al. (2004). The formulae for estimating the life table parameters are listed below (Table 1$)$. The age specific survival $\left(1_{\mathrm{x}}\right)$ and age specific fecundity $\left(\mathrm{m}_{\mathrm{x}}\right)$ at each pivotal age $(\mathrm{x})$ was worked out daily for the entire reproductive period to prepare fertility table.

\section{Results}

Development of immature stages of $B$. brevicornis on $C$. cephalonica from oviposition to adult emergence took 8 days at $28.3 \pm 0.1{ }^{\circ} \mathrm{C}$ and $59.6 \pm 0.6 \%$ r.h. The larval and pupal mortality was $6.08 \%$ and $10.25 \%$, respectively (Table 2 ). The sex ratio in the present study revealed a slightly male biased population (0.9). The female adults had a

Table 1

Formulae for assessment of life table parameters

\begin{tabular}{lcl}
\hline Life table parameters & Denoted by & Formulae \\
\hline Net reproductive rate & $\mathrm{R}_{\mathrm{o}}$ & $\sum 1_{\mathrm{x}} \mathrm{m}_{\mathrm{x}}$ \\
Approximate generation time & $\mathrm{T}_{\mathrm{c}}$ & $\sum \times 1_{\mathrm{x}} \mathrm{m}_{\mathrm{x}} / \Sigma 1_{\mathrm{x}} \mathrm{m}_{\mathrm{x}}$ \\
Innate capacity for increase & $\mathrm{r}_{\mathrm{c}}$ & $\log _{\mathrm{e}} \mathrm{R}_{\mathrm{o}} / \mathrm{T}_{\mathrm{c}}$ \\
Intrinsic rate of natural increase & $\mathrm{r}_{\mathrm{m}}$ & $\mathrm{e}^{-\mathrm{rm}} \times 1_{\mathrm{x}} \mathrm{m}_{\mathrm{x}}=1$ \\
Mean generation time & $\mathrm{T}$ & $\log _{\mathrm{e}} \mathrm{R}_{\mathrm{o}} / \mathrm{r}_{\mathrm{m}}$ \\
Finite rate of increase & $\lambda$ & $\operatorname{antiloge}^{\mathrm{rm}}$ \\
Weekly multiplication rate & $\mathrm{WMR}$ & $\lambda^{7}$ \\
Hypothetical female in $\mathrm{F}_{2}$ generation & $\mathrm{R}_{\mathrm{o}}{ }^{2}$ & $\mathrm{R}_{\mathrm{o}}{ }^{2}$ \\
Population doubling time & $\mathrm{DT}$ & $\log _{2} 2 / \mathrm{r}_{\mathrm{m}}$ \\
\hline
\end{tabular}


Table 2

Biological parameters of B. brevicornis on C. cephalonica

\begin{tabular}{lcr}
\hline Parameters & Range & Values** \\
\hline Larval mortality (\%) & $0.0-44.4$ & $10.3 \pm 2.2$ \\
Pupal mortality (\%) & $0.0-38.5$ & $11.0 \pm 2.1$ \\
Sex ratio (Female:Male) & $0.1-6.3$ & $1.2 \pm 0.2$ \\
Female longevity (days) & $6-31$ & $20.4 \pm 1.4$ \\
Male longevity (days) & $1-7$ & $3.2 \pm 0.3$ \\
\hline
\end{tabular}

** Values represent mean \pm standard error

longevity of 20.4 days while the males a meagre, 3.2 days. The life table and age specific fecundity was worked out (Table 3 ) based on which, the net reproductive rate $\left(R_{o}\right)$ was found to be 39.52 females per female during its lifetime and the approximate generation time $\left(\mathrm{T}_{\mathrm{c}}\right)$ was 14.68 days while, the precise generation time $(\mathrm{T})$ stood at 13.33 days (Table 4). Thus the parasitoid has the capacity to multiply 39.52 times in a generation time of 13.33 days. The intrinsic rate of increase $\left(r_{m}\right)$ was found to be slightly higher $(0.2758)$ than the innate capacity for increase $\left(r_{c}=0.2504\right)$. The finite rate of increase $(\lambda)$ was 1.318 nos. per day while, the weekly multiplication rate stood at 6.893 nos and 1561.83 females could be expected in the $\mathrm{F}_{2}$ generation.

\section{Discussion}

The development of immature stages of B. brevicornis on C. cephalonica from oviposition to adult emergence took 8 days at $28.3 \pm 0.1{ }^{\circ} \mathrm{C}$ and $59.6 \pm 0.6 \%$ r.h. and the sex ratio in the present study revealed a slightly male biased population (0.9). Male biased development was earlier reported by Singh et al. (2014) at 30 degree C. The female adults had a longevity of 20.4 days while the males a longevity of 3.2 days. Thus, augmentative parasitoid releases can be scheduled after 21 days after first release of parasitoids. Almost similar was the female longevity of Bracon hebetor (reared on C. cephalonica) (19.11 days), in experiments conducted by Farag et al. (2015), while the males had a longevity of 9.2 days. The net reproductive rate $\left(R_{o}\right)$ in the present studies was found to be 39.52 females per female during its lifetime with an approximate generation time $\left(\mathrm{T}_{\mathrm{c}}\right)$ of 14.68 days and a precise generation time ( $\mathrm{T}$ ) of 13.33 days. Thus, the parasitoid has the capacity to multiply 39.52 times in a generation time of 13.33 days. Slightly higher intrinsic rate of increase $\left(r_{m}\right)(0.2758)$ than the innate capacity for increase $\left(r_{c}=0.2504\right)$ suggest that the parasitoids have overlapping generations as opined by Southwood (1976). Laboratory experiments by Farag et al. (2015) revealed differences in the net reproductive rate $\left(R_{0}\right)$, intrinsic rate of increase $\left(r_{m}\right)$, finite rate of increase $(\lambda)$ and mean generation time $(T)$ which were 30.6 female/female/life time, 0.19, 1.2133 and 18.09 days, respectively. Almost similar values for innate capacity for increase $\left(r_{c}=0.2613\right)$, intrinsic rate of increase $\left(r_{m}=0.275\right)$, finite rate of increase $(\lambda=1.3168)$, weekly multiplication rate (WMR $\left.=6.86\right)$ 
Table 3

Life table and age specific fecundity of B. brevicornis on C. cephalonica

\begin{tabular}{|c|c|c|c|c|}
\hline Pivotal age in days (x) & $\begin{array}{l}\text { Proportion of survival of } \\
\text { female at different stages }\left(1_{x}\right)\end{array}$ & $\begin{array}{l}\text { No. of females produced per } \\
\text { female at different ages }\left(\mathrm{m}_{\mathrm{x}}\right)\end{array}$ & $1_{x} m_{x}$ & $\mathrm{xl}_{\mathrm{x}} \mathrm{m}_{\mathrm{x}}$ \\
\hline \multicolumn{5}{|c|}{ Immature stages 8 days } \\
\hline 9 & 0.92 & 2.04 & 12.7 & 16.9 \\
\hline 10 & 0.92 & 3.43 & 11.7 & 31.6 \\
\hline 11 & 0.88 & 4.45 & 11.2 & 43.1 \\
\hline 12 & 0.88 & 5.86 & 10.2 & 61.9 \\
\hline 13 & 0.80 & 5.20 & 10.1 & 54.1 \\
\hline 14 & 0.80 & 7.80 & 9.1 & 87.4 \\
\hline 15 & 0.72 & 2.56 & 9.1 & 27.6 \\
\hline 16 & 0.72 & 2.22 & 8.1 & 25.6 \\
\hline 17 & 0.68 & 2.53 & 7.5 & 29.2 \\
\hline 18 & 0.64 & 3.13 & 7.0 & 36.0 \\
\hline 19 & 0.56 & 0.93 & 6.9 & 9.9 \\
\hline 20 & 0.52 & 3.77 & 6.4 & 39.2 \\
\hline 21 & 0.52 & 5.62 & 5.4 & 61.3 \\
\hline 22 & 0.52 & 1.46 & 4.4 & 16.7 \\
\hline 23 & 0.40 & 1.50 & 4.6 & 13.8 \\
\hline 24 & 0.36 & 3.00 & 4.0 & 25.9 \\
\hline 25 & 0.36 & 3.78 & 3.0 & 34.0 \\
\hline 26 & 0.36 & 2.00 & 2.0 & 18.7 \\
\hline 27 & 0.16 & 6.25 & 2.9 & 27.0 \\
\hline 28 & 0.16 & 4.00 & 1.9 & 17.9 \\
\hline 29 & 0.08 & 2.50 & 2.3 & 5.8 \\
\hline 30 & 0.08 & 1.50 & 1.3 & 3.6 \\
\hline 31 & 0.04 & 3.00 & 1.5 & 3.7 \\
\hline \multirow[t]{2}{*}{32} & 0.04 & 3.00 & 0.5 & 3.8 \\
\hline & & & $\Sigma=39.52$ & $\Sigma=580.28$ \\
\hline
\end{tabular}

and population doubling time (DT $=2.52$ days) were observed by Singh et al. (2014) in their life table experiments with $B$. hebetor at 30 degree $C$. However they have reported a higher net reproductive rate $\left(\mathrm{R}_{\mathrm{o}}=92.0\right)$.

The higher female output and higher female longevity (up to 32 days) in the present study reveals that $C$. cephalonica possess the requisite nutritional quality for the growth and development of the larval parasitoid, B. brevicornis (Chandrababu et al., 1999). Earlier studies by Jhansi and Babu (2003) also revealed, C. cephalonica as a suitable host for mass rearing of the larval parasitoid, Bracon brevicornis with respect to oviposi- 
Table 4

Life table statistics of B. brevicornis on C. cephalonica

\begin{tabular}{lcc}
\hline Parameters & Denoted by & Statistics \\
\hline Net reproductive rate & $\mathrm{R}_{\mathrm{o}}$ & 39.52 females/female/life time \\
Approximate generation time & $\mathrm{T}_{\mathrm{c}}$ & 14.68 days \\
Precise generation time & $\mathrm{T}$ & 13.33 days \\
Innate capacity for increase & $\mathrm{r}_{\mathrm{c}}$ & 0.2504 \\
Intrinsic rate of natural increase & $\mathrm{r}_{\mathrm{m}}$ & 0.2758 \\
Finite rate of increase & $\lambda$ & 1.318 no./ day \\
Weekly multiplication rate & $\mathrm{WMR}$ & 6.893 nos \\
Hypothetical female in $\mathrm{F}_{2}$ generation & $\left(\mathrm{R}_{\mathrm{o}}{ }^{2}\right)$ & 1561.83 \\
Population doubling time & $\mathrm{DT}$ & 2.513 days \\
\hline
\end{tabular}

tion, hatchability, adult emergence and growth index. Thus, higher net reproductive rate, shorter population doubling time, higher female longevity, etc. indicate that $B$. brevicornis is an effective parasitoid for the management of black headed caterpillar in coconut ecosystems.

\section{Acknowledgements}

The financial assistance of the All India Coordinated Research Project (Palms), ICAR-Central Plantation Crops Research Institute, Kasaragod, Kerala, India is acknowledged.

\section{Literature}

CDB (2016): (http://www.coconutboard.gov.in/stat.htm), Last modified: October, 15, 2016.

Chandrababu, A., Gautam, R. D. and Garg, A. K. (1999): Biology of the ladybird beetle on aphid and mealybugs. Ann. Pl. Prot. Sci. 7, 13-18.

Cock, M. J. W. and Perera, P. A. C. R. (1987): Biological control of Opisina arenosella Walker (Lepidoptera: Oecophoridae). Biocontr. News Inf. 8, 283-310.

Farag, N. A., Ismail, I. A., Elbehery, H. H. A., Abdel-Rahman, R. S. and Abdel Raheem, M. A. (2015): Life table of Bracon hebetor Say (Hymenoptera: Braconidae) reared on different hosts. Intl. J. ChemTech. Res. 8, 123-130.

Gabre, R. M., Adham, F. K. and Chi, H. (2004): Life table of Chrysomya megacephala (Fabricius) (Diptera: Calliphoridae). Acta Oecol. 27, 179-183.

Jhansi, K. and Babu, P. C. S. (2003): Comparative biology of Bracon hebetor Say in two host insects. J. Appl. Zool. Res. 14, 165-168.

Jhansi, K. (1984): Studies on the Bracon hebetor (Say), a larval parasitoid of Maruca testulalis (Geyer). (Unpublished Master's thesis), Tamil Nadu Agricultural University, Coimbatore, India.

Mohamed, U. V. K. (1980): Studies on the entomophagous insects associated with Nephantis serinopa Meyr. (A report of the work done under P.L. 480 research project). University of Calicut, Kerala. 
Muthukrishnan, J., Srinivasaperumal, S. and Selvan, M. S. (1995): Bioenergetics and life tables of selected parasitoids and predators. In: T. N. Ananthakrishnan (ed.): Biological Control of Social Forest and Plantation Crops Insects. Science Publishers: Lebanon. pp. 193-206.

Nair, M. K. (1993): Opisina arenosella Wlk. The leaf eating caterpillar of coconut palm. Technical Bulletin No. 27, CPCRI, Kasaragod, India, 12 p.

Nampoothiri, K. and Thomas, V. (2000): The present scenario of coconut, arecanut and cocoa in India. In: Proc. International Conference on Plantation Crops, PLACROSYM XIV, Hyderabad, India, 12-15 December, Souvenir, $8015 \mathrm{p}$.

Narendran, T. C., Mohammed, U. V. K., Abdurahiman, U. C. and Kumar, V. V. S. (1980): Oviposition behaviour of Bracon brevicornis Wesmael (Hymenoptera: Braconidae). Agric. Res. J. Kerala, 18, 239-241.

Rukshana, K. and Majeed, P. P. (2014): The effectiveness of biocontrol of Opisina arenosella (Lepidoptera: Oecophoridae) using Bracon brevicornis (Hymenoptera: Braconidae). J. Zool. Stud. 1, 1-3.

Singh, D., Mathew, I. L. and Singh, R. P. (2014): Influence of different diets on intrinsic rate of natural increase $\left(\mathrm{r}_{\mathrm{m}}\right)$ of Bracon hebetor (Say) (Hymenoptera: Braconidae) reared on Corcyra cephalonica Stainton (Lepidoptera: Pyralidae). Biolife 3, 653-656.

Southwood, T. R. E. (1976): Ecological Methods with Particular Reference to the Study of Insect Populations. Chapman and Hall, London, pp. 1-391.

Venkatesan, A., Jalali, S. K., Murthy, K. S., Rabindra, R. J. and Rao, N. S. (2004): Comparative life table studies of Goniozus nephantidis (Muesback) (Hymenoptera: Bethylidae) on three different lepidopteran insect pests. Ann. Pl. Prot. Sci. 12, 5-8. 